\title{
Boris Schatz, Abel Pann and the Bezalel School of Arts and Crafts in Jerusalem \\ Batsheva Goldman-Ida
}

Curator Emeritus, Tel Aviv Museum of Art, Shaul Hamelech Blvd, 27, Tel Aviv, Israel

Email: batsheva@goldman.org

\begin{abstract}
This essay discusses the early Bezalel School of Arts and Crafts in Jerusalem (1906-1929), highlighting the connection to Vilnius of its founder Professor Boris Schatz and of one of its teachers, Abel Pann. While Prof. Schatz represents a more academic painting style, Abel Pann is a representative of a modernist style. KEYWORDS: Arts \& Crafts Movement, Bezalel School of Arts and Crafts, La Ruche, Peredvizhniki, Zionism, Vilnius Academy of Art, Mark Antokolsky, Theodor Herzl, Ephraim Moses Lilien, Yehuda Pen, Abel Pann (Abba Pfeffermann), Ze'ev Raban (Wolf Rawicki), Prof. Boris Schatz
\end{abstract}

To date, the early Bezalel School of Arts and Crafts has been presented in a comprehensive exhibition and catalogue at the Israel Museum in Jerusalem. ${ }^{1}$ Yigal Zalmona published on Boris Schatz twice, in 1985 and in 2006. ${ }^{2}$ Professor Schatz was a prolific writer, who kept diaries and wrote utopian novels. ${ }^{3}$ Along with the administrative logs, syllabi, and other original documents from the early Bezalel School, his correspondence is kept at the Central Zionist Archives in Jerusalem, Dossier L42.

I have contended the premise that Prof. Schatz developed the artistic style of the School. Instead, in a comprehensive 2001 exhibition at the Tel Aviv Museum of Art and a monograph on Ze'ev Raban, ${ }^{4}$ I suggested that Raban, who joined in 1912 and had a background in object design and illustration - as opposed to Schatz' sculptural background - implemented Schatz's ideals using his own platform of

1 See: Bezalel, 1906-1929, ed. Nurit Shilo-Cohen. Jerusalem: The Israel Museum, 1983.

2 See: Yigal Zalmona, Boris Schatz. Jerusalem: Art and Culture Council, 1985, and Boris Schatz: The Father of Israeli Art. Jerusalem: The Israel Museum, January-June 2006 [exhibition catalogue].

3 See: Boris Schatz, Boris Schatz - His Life \& Work: A Monograph. Jerusalem: B'nai Bezalel, 1925, and Jerusalem Rebuilt (Jerusalem: Bezalel, 1924) (in Hebrew, https://rosetta.nli.org.il/delivery/DeliveryManagerServlet?dps_ pid=IE48944100)

4 See: Zéev Raban: A Hebrew Symbolist. Tel Aviv: Tel Aviv Museum of Art, and Jerusalem: Yad Izhak Ben-Tzvi, 2001 [exhibition catalogue, in Hebrew, with an English summary]. 
Symbolist art. I had also curated an earlier exhibition on Ze'ev Raban in New York in 1983. ${ }^{5}$ Gideon Ofrat, another author who has published extensively on this subject, also wrote for the New York show.

Gideon Ofrat and Yigal Zalmona devote chapters to the early Bezalel School of Art in their general overviews of Israeli art, ${ }^{6}$ and Doreet LeVitte Harten wrote about this school in her publication in German. ${ }^{7}$

Other authors who have discussed the early Bezalel school include Dalia Manor, Inka Bertz, Margaret Olin, Michael Berkowitz, and, more recently, Alec Mishory. ${ }^{8}$

The Bezalel School of Art was represented at a major Berlin Exhibition of Jewish Artists in 1907, although the organizers were not Zionists.

Doctoral dissertations have been written on this topic, the most cogent among them by Natalia Berger and Ilona Oltuski. ${ }^{10}$

Regarding Abel Pann, the Mayanot Gallery in Jerusalem and the Israel Museum have exhibited his works. ${ }^{11}$

Founded in 1906 through 1929, the Bezalel School of Arts and Crafts was initially envisioned by Prof. Boris Schatz (1867-1932) as a complex of three distinct

5 See: Ze'ev Raban, Jerusalem's Forgotten Master. New York: Yeshiva University Museum, 1983 [exhibition catalogue].

6 See: Gideon Ofrat, One Hundred Years of Art in Israel, tr. Peretz Kidron. Boulder: Westview Press in cooperation with the Mizel Museum of Judaica, 1998; Zalmona, Yigal, 100 Years of Israeli Art. Farnham: Lund Humphries in Association with the Israel Museum, Jerusalem, 2013.

7 See: Die neuen Hebräer - 100 Jahre Kunst in Israel, Ed. Doreet LeVitte Harten. Berlin: Nicolai, 2005.

8 See: Dalia Manor, Art in Zion: The Genesis of Modern National Art in Palestine. Routledge: 2004; Dalia Manor, "Biblical Zionism in Bezalel Art", Israel Studies 6:1 (Spring 2001): 55-75; Inka Bertz, "Trouble at Bezalel: Conflicting Visions of Zionism and Art", in: Nationalism, Zionism and Ethnic Mobilization of the Jews in 1900 and Beyond, ed. Michael Berkowitz. Leiden-Boston: Brill, 2004, 247-284; Inka Bertz, "Jewish Renaissance - Jewish Modernism", in: Berlin Metropolis: Jews and the New Culture, 1890-1918, ed. Emily D. Bilsky. Berkeley et al: University of California Press, 1999 [exhibition catalogue]; Margaret Olin, The Nation without Art: Examining Modern Discourses on Jewish Art. Lincoln: University of Nebraska Press, 2001; and Zionist Culture and West European Jewry Before the First World War. Chapel Hill: University of North Carolina, 1993; Alec Mishory, Secularizing the Sacred: Aspects of Israeli Visual Culture. Boston-Leiden: Brill, 2019.

9 See: Batsheva Goldman-Ida, Fragmented Mirror, Exhibition of Jewish Artists, Berlin 1907. Tel Aviv: Tel Aviv Museum of Art, 2009 [exhibition catalogue].

10 See: Natalia Berger, The Jewish Museum: History and Memory, Identity and Art From Vienna to the Bezalel National Museum, Jerusalem. Leiden-Boston: Brill, 2018; Ilona Oltuski, Kunst und Ideologie des Bezalels in Jerusalem: Ein Versuch zur jüdischen Identitätsfindung. Frankfurt am Main: Kunstgeschichtliches Institut de Johann-Wolfgang-Goethe-Universität, 1988.

11 See: Abel Pann 1883-1963, with introductions by Gideon Ofrat and Yigal Zalmona. Jerusalem: Mayanot Gallery, 1987 [exhibition catalogue]; Yigal Zalmona and Tami Manor-Friedman, Old-New Land: Abel Pann Paints the Bible. Jerusalem: The Israel Museum, 2003-2004 [exhibition catalogue, translated into French and German]; Die Kunst des Abel Pann: vom Montparnasse ins Land der Bible. Jerusalem: The Israel Museum, 2005 [exhibition catalogue; also available in French and English]. See also: Yigal Zalmona, Tamar Manor-Friedman, Kadima - The East in Israeli Art. Jerusalem: The Israel Museum, 1998 [exhibition catalogue]. 
entities: an art school, a museum, and a crafts workshop. The idea to establish the school was raised at the Seventh Zionist Congress in 1905 in Basel, following an emotional encounter between Prof. Boris Schatz, its founder, and Theodor Herzl (1860-1904), the Zionist leader, in 1903, when the school's name was discussed in the context of the biblical artisan Bezalel, who had presided over the building of the Tabernacle in the Wilderness.

In 1903, Boris Schatz presented his plan for a school of art in Jerusalem before Theodor Herzl, the founder of modern political Zionism. The Bezalel School of Arts and Crafts, founded by Schatz in 1906, was in effect realized thanks to Herzl's support and the Zionist Committee in Berlin. In his description of that meeting, Schatz refers to Herzl in terms of recalling the biblical Moses on Mount Nebo, who looked from afar on the land of Israel knowing he would not enter it.

"Good, we shall do that", Herzl said quietly and resolutely. And after a brief pause, he asked: "What name will you give to your school?"

"Bezalel”, I answered, "after the name of the first Jewish artist who once built a temple in the wilderness".

"A temple in the wilderness", he repeated slowly, and the beautiful sad eyes seemed to look into an endless vista, as though he felt that he would never see it himself. ${ }^{12}$

The analogy between Herzl and Moses is given a visual expression in a copper relief that Schatz created in 1904 upon Herzl's death (Fig. 1). On the right is a relief of Schatz's Moses on Mt. Nebo, first created as a sculpture and a painting in circa 1890 when Schatz was serving as an apprentice to the Russian-Jewish sculptor Mark Antokolsky (1843-1902) in Paris from 1889 to 1895 . A relief of Herzl is on the left. The famous saying of Herzl in Hebrew, 'If you will it, it is no dream', runs across the bottom of the plaque. The opening lines of

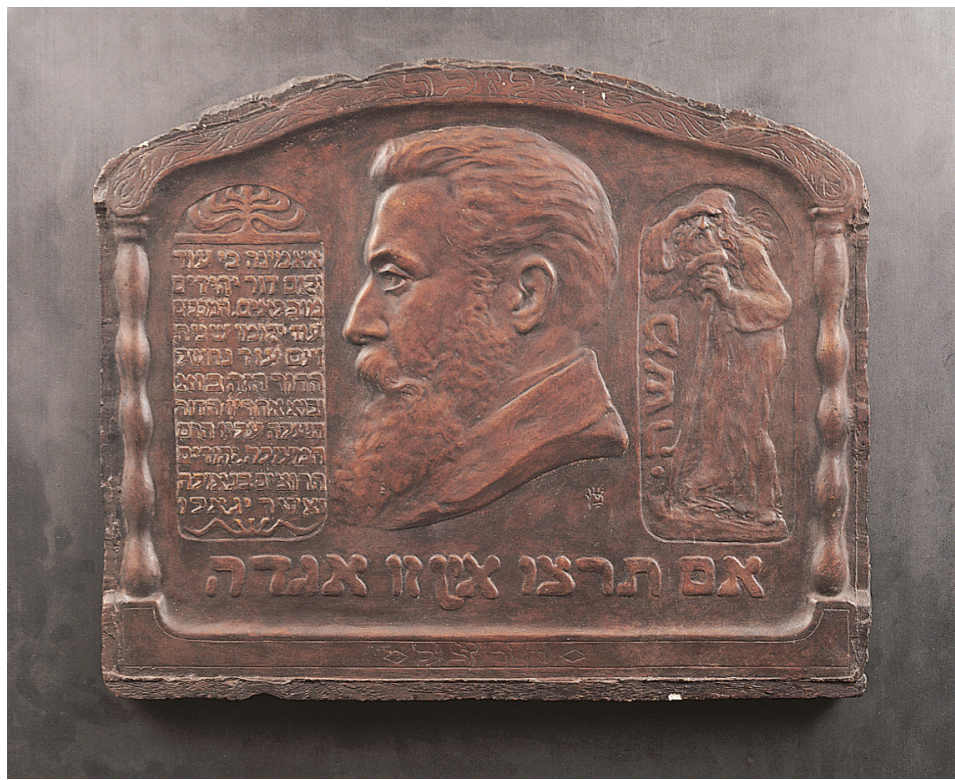

Fig. 1. Boris Schatz, Herzl Memorial Plaque. Around 1921 (original 1904). Painted plaster relief, $36.5 \times 63$. Collection of the Tel Aviv Museum of Art 
the text on the left come from the ending of Herzl's The Jewish State (1896): “Therefore I believe that a wondrous generation of Jews will spring into existence. The Maccabees will rise again". ${ }^{13}$

Thus, the very initiative for the school stemmed from the Zionist ideals and the elevation of biblical heroes. In the artistic style promoted by Schatz, one can find a certain affinity with the realism of the Russian Peredvizhniki, or the Wanderers' group, who aspired to express in their creations the spirit of the people, and one that Antokolsky also identified with. In fact, Schatz was antagonistic to modern art, saying, for example, "Why does one talk so much about modern art? Because there is nothing to see!" 14 By the 1890 s, however, this style was already anachronistic. Furthermore, the Jugendstil or German Art Nouveau style of Ephraim Moses Lilien (1874-1925), who assisted Schatz in 1906 in opening the school, had also become old-fashioned by the early twentieth century, to be replaced by Art Deco.

For Schatz, one purpose of the proposed museum collection of artefacts and of ritual and folk art to become the nucleus of what is now known as the Israel Museum of Jerusalem was to provide a source of motifs and symbols to use in the crafts workshop. In this manner, Schatz hoped to establish a new and unique national art style, similar to what Schatz had developed while in Bulgaria working for the king and his newly emancipated country from 1895 to 1905 , but in this case a new Hebrew style. The reliance on symbolic motifs for embellishing objects relates to Schatz's demand to integrate Jewish visual motifs, such as ancient coins, in the art works of the school. To this end, Schatz copied the decoration on Hellenistic coins used by the Maccabees that featured such motifs as the seven-branched menorah, the fleur-de-lis, and more. The motifs were then copied in the Bezalel school design books and used as decoration on its home and synagogue objects. Yet, Charles Robert Ashbee (1863-1942), who was a former member of John Ruskin and William Morris' circle in the Arts \& Crafts movement in England and an advisor to the Jerusalem governor Ronald Storrs from 1918 to 1922, thought otherwise. He declared: "Neither the most exquisite cameos of Professor Schatz nor the peppering of any number of 'blessed menorahs' on carpets and silver match boxes will ever produce a Jewish style". ${ }^{15}$ Thus, controversy and criticism accompanied the school, while the utopian and visionary Schatz remained a steadfast optimist.

The school was essentially a Zionist enterprise, funded by the Zionist Committee of Berlin that hoped to commercialize the thriving home industry of carpet weaving

13 Herzl 1988: 156-7; see also: Goldman-Ida 2005: 235.

14 Schatz 1924: 15-17.

15 An underlying bias of Ashbee was that due to the Second Commandment the Jews were incapable of creating plastic art. He prefaced his above remarks: "The divine command is in your bones, and you cannot and never will, if you are a genuine Jew, create a plastic art." Ashbee 1983: 247-8. 
(Fig. 2). There was a dissonance between Prof. Schatz's desire to create a new style of Hebrew art by combining local scenery and population, ancient Hebrew symbols and the fine arts, and the economically-driven idea of creating craft objects for export, which reverberated throughout its existence from 1906 to 1929. The first department of the school in 1906 was designated for carpet weaving. Many of the young pupils - some 45 out of 400 candidates - had been working previously in this area, for example, in a weaving workshop set up by Sir Moses Montefiore in 1850, and the Alliance Israélite Universelle school of Bible Studies and Crafts.

Additional workshops were added in 1909 (silver filigree, wood and stone carving, and frame making) and in 1910 (cane furniture, repoussé, and lithography). Abel Pann

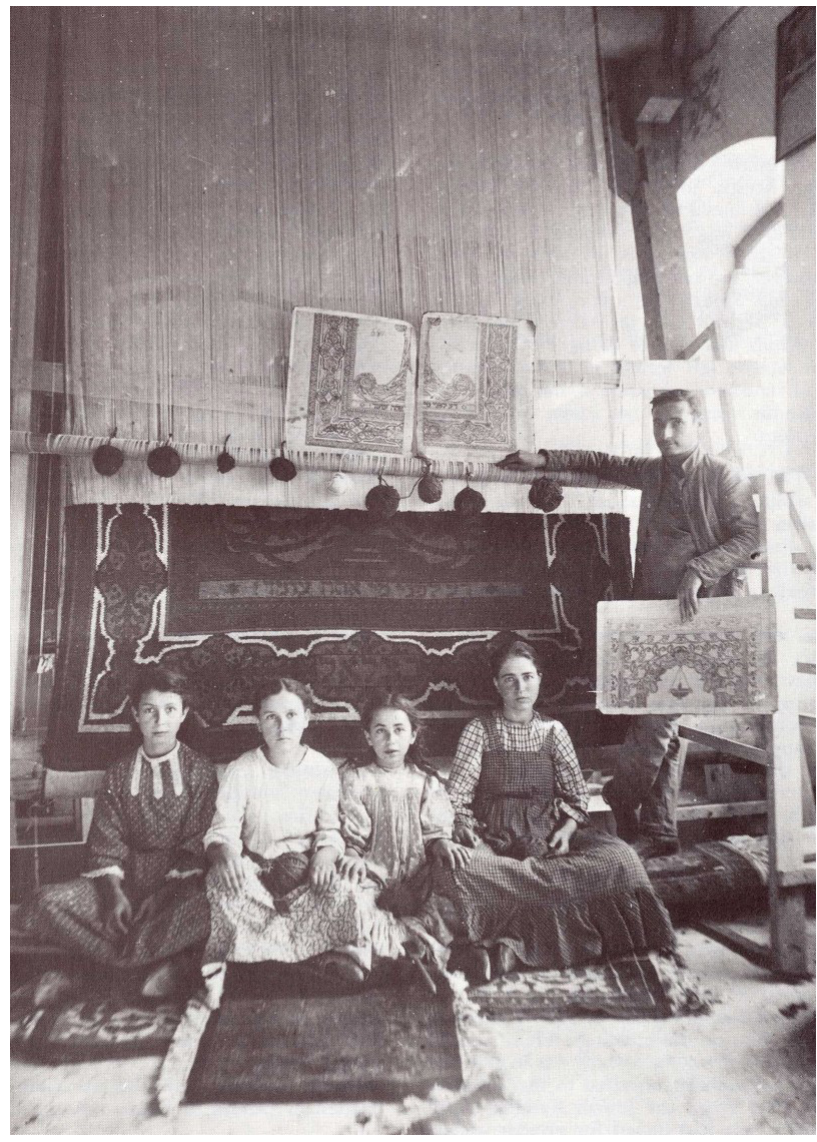

Fig. 2. A carpet weaving workshop at the Bezalel School of Art, Jerusalem, 1908, with teacher Shmuel Ben-David (1884-1927) standing at far right. Collection of the Israel Museum, Jerusalem (1883-1963) brought its first lithographic press to Bezalel in 1921 from Vienna and began the Graphica or graphics department. ${ }^{16}$ In all, some 30-35 crafts were taught. When in 1913 the Zionist Committee of Berlin sent an executive director to replace Prof. Schatz, which was prompted by the unproductive revenue of the school, the workshops disassociated themselves from the Bezalel proper and operated independently, often receiving commissions through Prof. Schatz. By 1920, however, 23 of the craft workshops resumed their activity.

The student population and the number of workers in crafts workshops grew steadily from 140 in 1906 to 269 in 1911 and to 450 in 1912. During World War I, the number dropped drastically. However, at the beginning of 1916, the numerous departments of the school worked together under the direction of Raban and created

16 The first lithographic press was founded in the Old City of Jerusalem in 1892 by Abraham Leib Monzon, II (c. 1871-1930). I am related to this family through her paternal grandmother. 


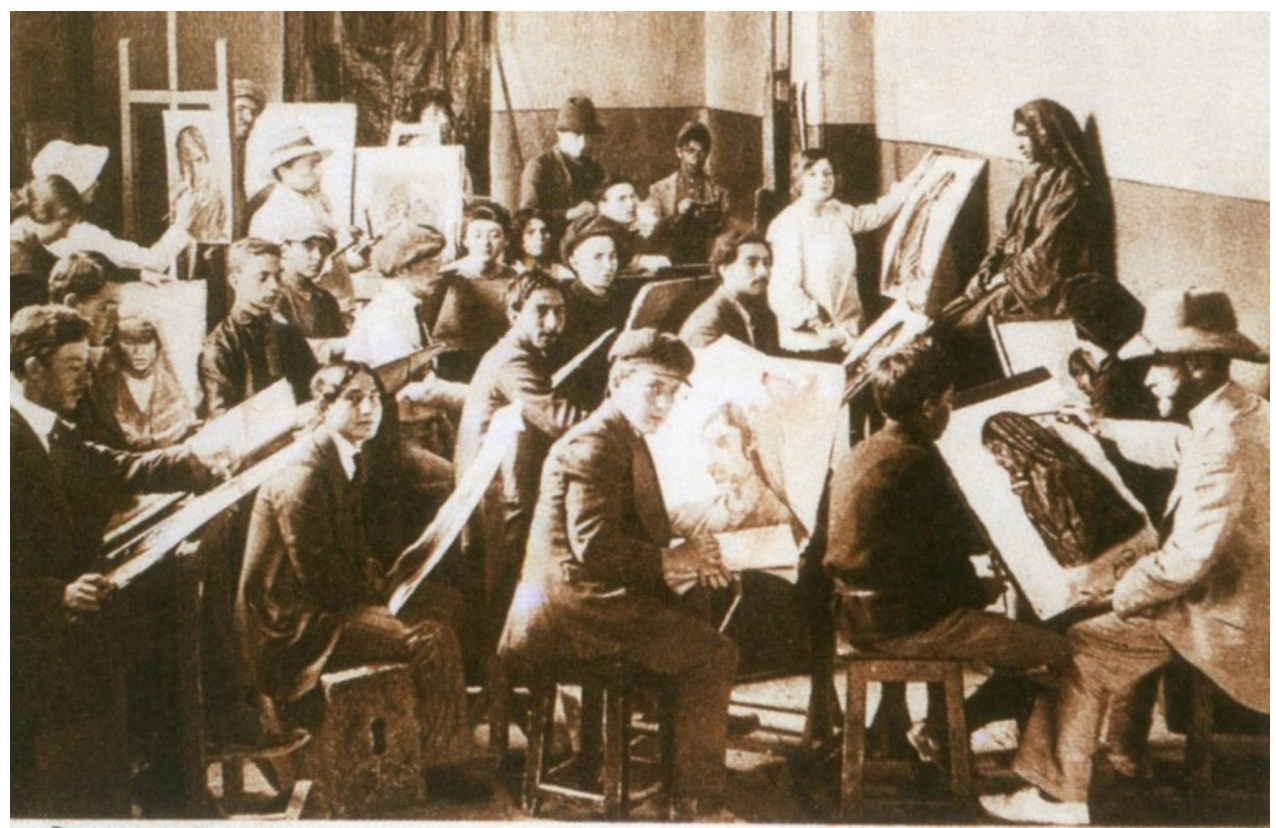

Fig. 3. Live model drawing class at the Bezalel School of Art, Jerusalem, 1913, with teacher Abel Pann (with a hat) at far right. Collection of the Israel Museum, Jerusalem

two major works - the Elijah Chair and the Torah Ark. The school resumed its activities in 1920, with the return of Abel Pann and other art teachers to Bezalel. Then, due to financial difficulties, the school closed down in 1927, only to be reopened in 1928. By 1929, however, it closed again. Still, the workshops continued to thrive and the Bezalel logo and design could still be found on objects through to the 1950s.

Yemenite and Oriental Jews served as models of the ideal Hebrew type for the students. They also worked as artisans for the school, mainly as silversmiths and stone carvers. From 1911 to 1913, a community of Yemenite Jews near Ben Shemen was associated with the Jerusalem Bezalel School.

Regarding the fine arts, among the early teachers at Bezalel were Abel Pann, of whom we shall speak presently, and Ze'ev Raban (Wolf Rawicki) (1890-1970) from Łódź. He came to Palestine from Paris and taught painting in the open air and from live models and the techniques of sculpture, from plaster casts to bronzes (Fig. 3).

Raban, who joined the staff in 1912 through 1929, was the artist who defined what came to be known as the Bezalel style. While Schatz retained elements of academic art, Raban worked from the sophisticated base of symbolist and idealist art, Freemasonry and anthroposophy. Symbolism is not just one aspect of Raban's art: it provides the key to the appreciation of his entire artistic oeuvre. Symbolist art relies more on ideas and symbols than on a naturalistic or realistic depiction. An integral part of composition in Symbolism and Art Nouveau neglects the individual features of objects in favour 
of those that are purely typical. It is concerned neither with particular people as individuals nor with particular facets of the visible world, but rather with an archetypal woman or an archetypal landscape. Schatz, too, worked from archetypes, seeking to inculcate or teach an ethos based in religious types and historical figures. The figures were collective images. For Raban and for Schatz, the interest in the myth, the dream, and the allegory was directed toward the revival of biblical and legendary tales as a way of strengthening self-identity and the Zionist ethos in Palestine.

Raban and Schatz arrived in Palestine in the midst of a wave of immigration called the Second Aliyah (1904-1918), joining some 30,000 other enthused Zionists. The immigrants of the Second Aliyah called themselves Halutzim or Pioneers and referred to themselves as "Hebrews", differentiating themselves from the Ghetto Jews of the Diaspora. The "New Hebrews" were to revive the Hebrew language, engage in sports, the arts, and agricultural work, and through their return to the land of the Bible realize themselves as complete individuals. Raban considered himself a Pioneer in the renewal of Hebrew art in Palestine and referred to himself as a Zionist.

Bezalel artists participated in "The First Art Exhibition in the Land of Israel" in Tel Aviv in 1920 organised by Yakov Peremen (1881-1960), and in the two "Tower of David" exhibitions in Jerusalem in 1921-1922. ${ }^{17}$ However, Schatz's romanticist and academic art style incited an increasing number of students to challenge his artistic background. Raban's symbolist style, which was the last great artistic style of the nineteenth century according to the art historian Meyer Shapiro, had also become passé by the first quarter of the twentieth century. For these reasons, modernist-inclined artists looked beyond Bezalel to realise their artistic ambitions. Many former Bezalel students, who studied in Paris in the 1910s and the 1920s, subsequently moved to Tel Aviv to establish a modernist art school or settled in Jerusalem. Among them were Arie Aroch, Ze'ev Ben-Zvi, Reuven Rubin, Nahum Gutman, Israel Paldi, Sionah Tagger, Moshe Castel, Pinhas Litvinovsky, Menahem Shemi, Yosef Zaritsky, Haim Gliksberg, Arieh Lubin, Avigdor Stematsky, and Yehezel Streichman.

In 1935, Joseph Budko was chosen to direct the renamed school, the New Bezalel, whose orientation was entirely different. Budko had studied at a yeshiva near Vilnius, was apprenticed as a metal-worker, and studied painting in Vilnius. He later studied with Hermann Struck in Berlin and was influenced by Käthe Kollwitz, German Expressionism, and the Neue Sachlichkeit. By 1964, the New Bezalel evolved into what today is considered the best art school in Israel - the Bezalel Academy of Art and Design on the Givat Ram Campus of the Hebrew University in Jerusalem.

Prof. Schatz's vision of the school as a centre for fine arts relying on motifs from archaeology, botany, and folk-art to create a new national art reaches back to a special configuration of forces in the Vilnius area. An advocate of national

17 Zalmona 1991. On Peremen, see: Voiskoun 2006. This catalogue was published in Hebrew and Russian. I have prepared an English translation that is available on request. See also: Donner 2002. 


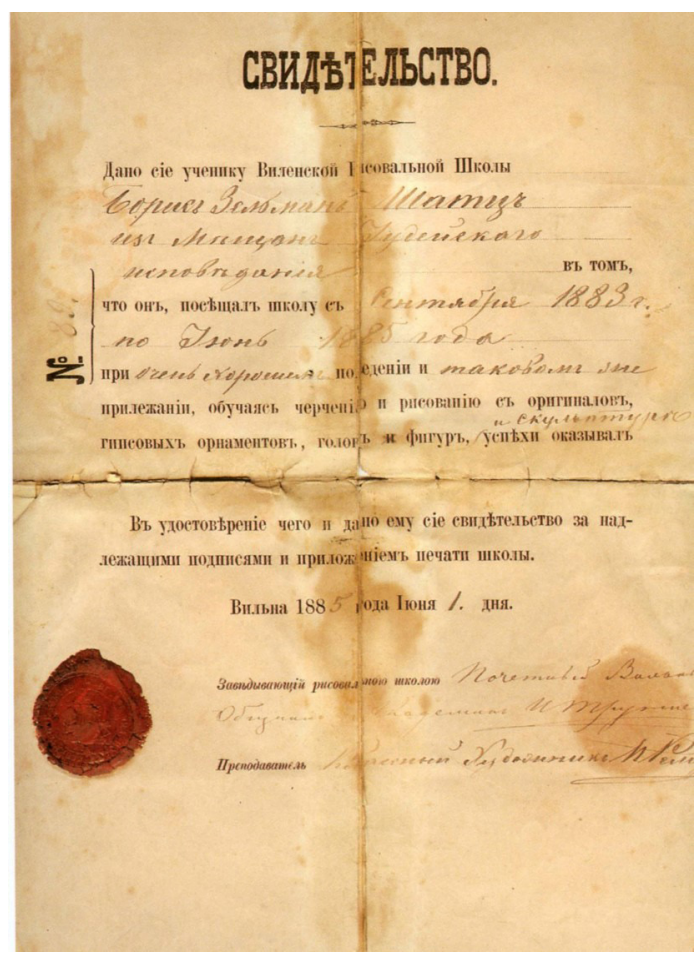

Fig. 4. Boris Schatz's diploma from the Vilnius School of Drawing. 1885. Collection of the Israel Museum, Jerusalem

culture, the art and music critic Vladimir Stasov (1824-1906) encouraged the famous sculptor Mark Antokolsky, whom Schatz first met in Vilnius in July 1887, to engage in works related to his own culture. Later, Stasov collaborated with Baron David Günzburg (1857-1910) on an album of Hebrew manuscripts L'ornament hebreu, published in 1905, and a translation of the article "On Jewish Art" by Vladimir Stasov, first published in $1872 . .^{18}$

Although Schatz initially arrived to Vilnius to study at a yeshiva, a Jewish institute of higher learning. At this time, he also met the local chapter of the "Lovers of Zion" (Heb. Hovevei Zion), with whom he associated, and the Haskalab (Jewish Enlightenment) writer Peretz Smolenskin (1842-1885). Thus, Schatz came to Vilnius at the age of 15 and stayed in the city from 1882 to 1887 . During these formative years, he came to study at a yeshiva, but soon left, and from September 1883 to June 1885 he was enrolled at the Vilnius Drawing School (1866-1915) (Fig. 4) ${ }^{19}$ and taught painting in this city afterwards. His commitment to fine arts, Zionism, and political activism began in Vilnius.

Let us learn more about this extraordinary individual and his work, and that of Abel Pann, the artist from Kreslawa, whom he sought out to join him at the Bezalel School in 1913.

Boris (Shlomo-Zalman-Dov-Baruch) Schatz was born to a rabbinic family in Varniai, Lithuania, in 1866. While still a child, he decorated the synagogue Mizrah (prayer) plaques with drawings of "fantastic animals and plants, thickly interspersed with Bible quotations and sayings of the wise, ${ }^{20}$ designed the Parochet (Torah ark canopy), and more. When in the yeshiva, he copied Sefer Raziel, 'including the illustrations representing

18 Günzburg, Stasov 1905. For an English translation of Stasov's article originally published in 1872, see: Vasilieva, Zaikovsky, Kantsedikas 2003.

19 Šrkaitė 2017.

20 Schatz 1925: 7. 
a sort of the cabalistic type of birds and beasts, ${ }^{21}$ thus forming a familiarity with Jewish ritual art and imagery from an early age.

His formal art studies began in Vilnius at the School of Drawing from 1883 to 1885. Subsequently, in 1888 , he studied medallion minting, metalwork relief, and sculpture in Warsaw; that same year, he published an article on Jewish crafts in the Hebrew journal Ha-Tzefirah. ${ }^{22}$ When in Vilnius, he met the sculptor Mark Antokolsky and from 1889 to 1895 he worked as his apprentice in Paris (Fig. 5) while studying at the art studio of Fernand Cormon (1845-1924) (Fig. 6). At the invitation of Prince Ferdinand of Bulgaria, he spent the next ten years - from 1895 to 1905 - in Sofia, founding an art academy and promoting nationalistic and folk art. Here he became engaged in monumental sculpture and the minor arts.

Dr Mordechai Ehrenpreis (1869-1951), the chief rabbi of Bulgaria from 1900 to 1914, introduced Schatz to the Zionist movement and its leader, Theodor Herzl (1860-1904). In early 1903, the two met and agreed to establish the Bezalel School of Art in Jerusalem, and, following a stay in Berlin in 1905 at the home of E. M. Lilien (1874-1925), Schatz and Lilien set forth to realize the school in 1906 . Thenceforth and up until 1929, under the auspices of the Berlin Committee, Prof. Schatz would serve as director of the school and, at times, of the workshops associated with it. When the Committee sent their recommended

21 Ibidem, 10. This grimoire was first published in Amsterdam in 1701: Sefer Raziel ha'Malakh (in Hebrew). Amsterdam: Avraham Mendes Qavitinyo, 1701; https://www.hebrewbooks. org $/$ pdfpa ger.aspx ?req $=23968 \&$ st $=\&$ pgnum $=1$ \&hilite $=$ For English translation, see: https://www.esotericarchives.com/ raziel/raziel.htm.

22 HaTzefirah, 1612 1888: 3.

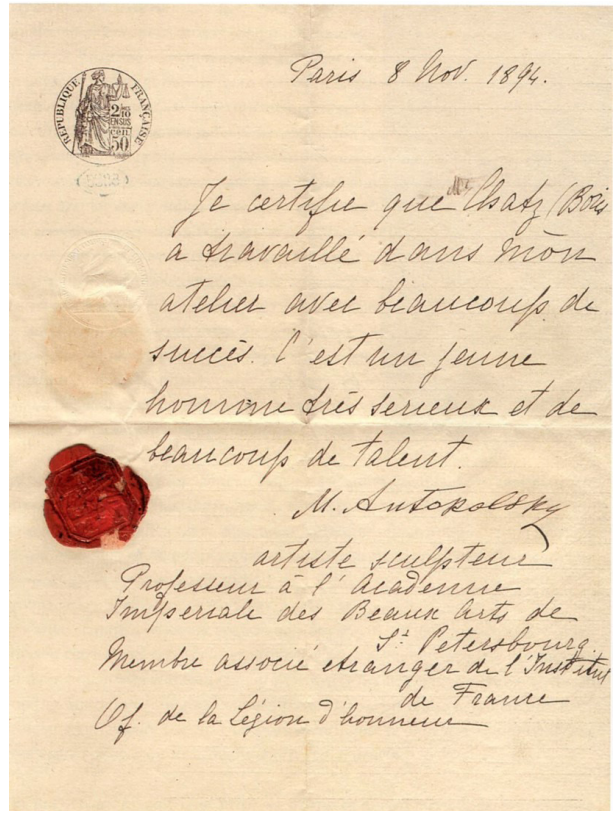

Fig. 5. Mark Antokolsky's letter of recommendation to Boris Schatz. Paris, 1894. Collection of the Israel Museum, Jerusalem

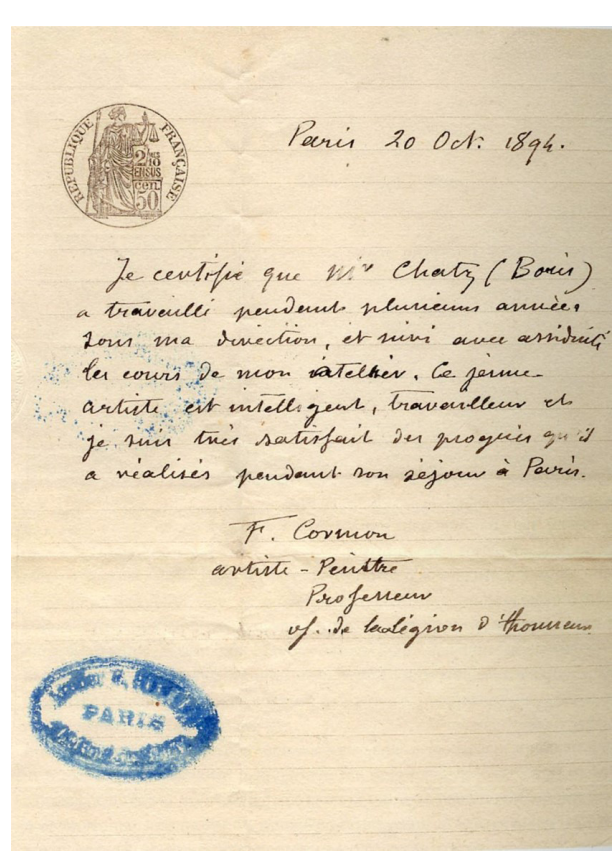

Fig. 6. Fernand Cormon's letter of recommendation to Boris Schatz. Paris, 1894. Collection of the Israel Museum, Jerusalem 


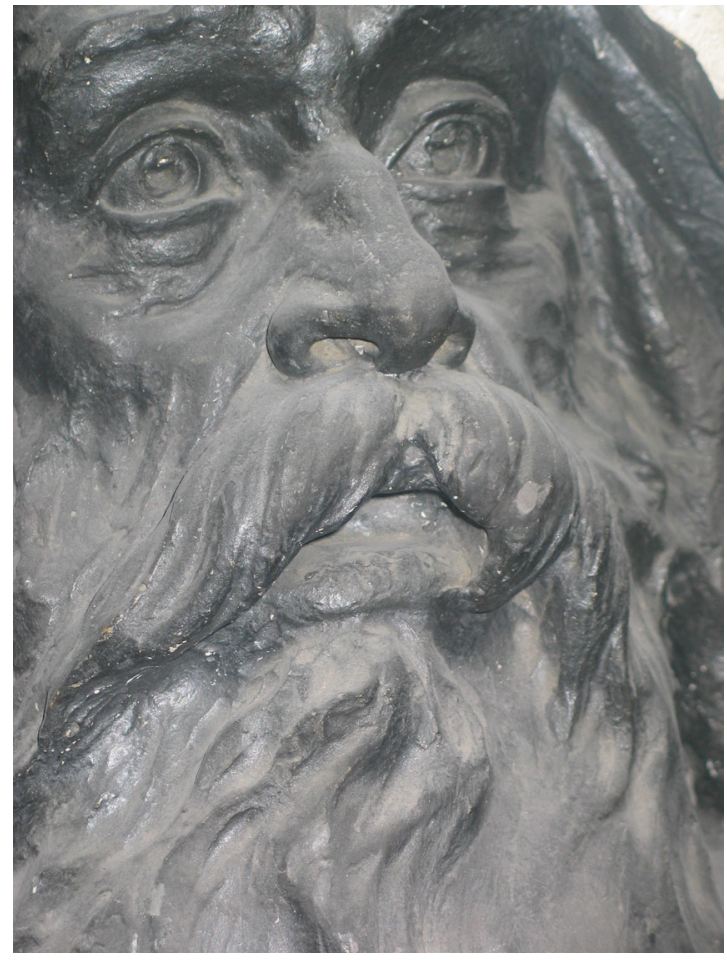

Fig. 7. Boris Schatz. Head of Mattathias the Maccabee. 1894. Plaster, h $52 \mathrm{~cm}$ (detail. ). Collection of the Tel Aviv Museum of Art teachers to the Bezalel, however, as in the case of Richard Goldberg and his son Erich in 1911, Schatz recruited instead the Eastern European artists Ze'ev Raban and Abel Pann, who were from a background similar to his own.

Schatz's sculptural oeuvre is influenced by the Russian Peredvizhniki or the Wanderers' Group, who aspired to express the spirit of the people in their works. Following the Kishinev pogrom in 1903, Schatz embarked on a series of bronze reliefs on Jewish life, a theme he returned to in 1913-1914. While on holiday at Banyuls-sur-Mer in 1890 , Schatz conceived statuary of ideal figures from Biblical and Hellenistic history, including a Moses cycle and Mattathias the Maccabee, executed at the time of the Dreyfus trial in 1894. Reliefs depicting the awaiting of the Messiah and the prophets were produced following the Balfour Declaration of 1917. From 1928 to 1929, Schatz began a series of bronze heads of prominent Jewish and Zionist figures.

In the collection of the Tel Aviv Museum of Art, there is a painted plaster head of Mattahias the Maccabee (1894), signed in Russian (Fig. 7), probably produced in Paris at the same time as the full-length figure (now lost) that is considered the major work of the artist. The same sense of power and movement is present as in the full-length figure, with wind-blown hair and the beard, wide-open expressive eyes, and a furrowed yet determined brow confronted with fear and overcoming it at the same time. A smaller ceramic version in a private collection attests to Schatz's work at the Georges Dreyfus Ceramics Company in Paris at the time. Another version of the head was produced in 1903, when the title "Mattityahu" was added on in Hebrew on the right side of the base. The model for the work was Schatz's maternal grandfather: "an ancient old man, with long, snow-white peyes [side locks] and a beard, a beautiful, dry, regular face, high, well-rounded brow, and youthful black eyes, ${ }^{23}$ who, as Schatz explains, he "perceived [while at Banyuls-sur-Mer, as] a stately old man, with the youthful heroic heart of a Maccabee". ${ }^{24}$

23 Boris Schatz 1925: 3.

24 Ibidem: 26. 
Characteristic of Schatz's sculptural reliefs and heads is the expressive use of hands for pathos and emotion. This may also be seen in a series of ten self-portraits in oil executed in 1932, when Schatz was incapable of engaging in sculpture due to his poor health. The Museum collection owns Schatz's 1932 self-portrait in oil, which shows him in an especially pensive mood, with one hand holding his head and the other resting on the table. This portrait was reproduced as an etching by the Bezalel artist Jacob Eisenberg (1897-1965) (Fig. 8). The dark background of the portrait with the well-lit face recalls a 1909 self-portrait of Jozef Israëls, itself influenced by Rembrandt's portraits, given to Schatz as a gift. ${ }^{25}$ However, the expressive use of the hands

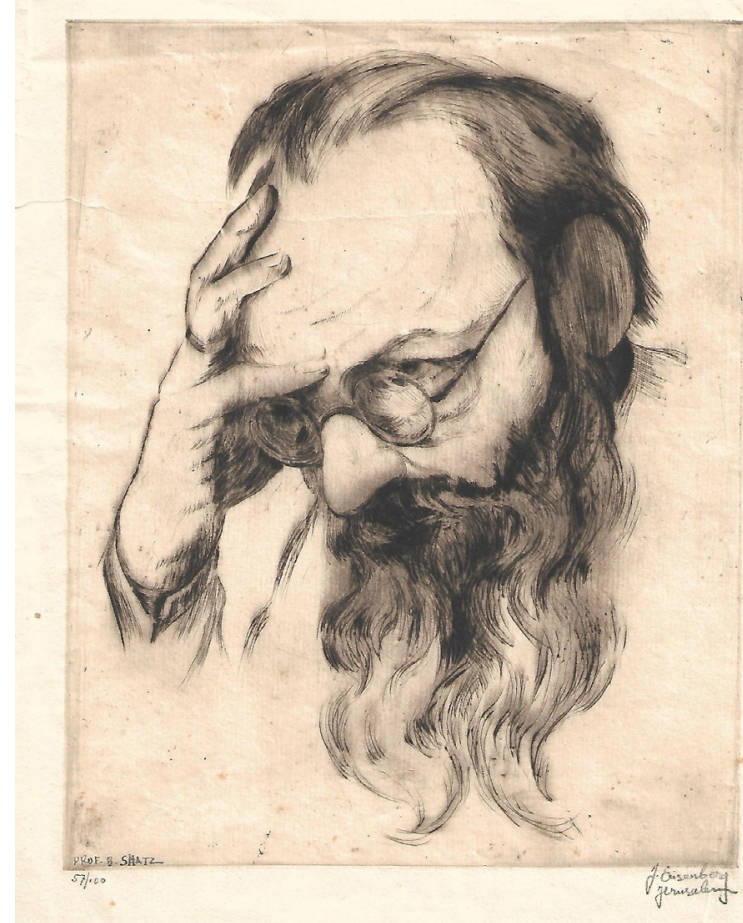

Fig. 8. Jacob Eisenberg, Portrait of Prof. Boris Schatz, Jerusalem. C. Around 1932. Lithograph, paper, $30.7 \times 23.5 \mathrm{~cm}$; image: $22.3 \times 27.5 \mathrm{~cm}$. Signed left: "PROF. B. SCHATZ", signed right: "J. Eisenberg/Jerusalem", and numbered 57/100. Private collection in the self-portrait is unique to Schatz and epitomizes his industrious endeavours.

Schatz passed away in 1932 in Denver, Colorado, USA, while on a fund-raising mission. ${ }^{26}$

Abel Pann (Abba Pfeffermann) was born in 1883, in Kreslawka, Vitebsk region. He studied briefly in Vitebsk with Yehuda Pen (1854-1937) and subsequently worked in Vilnius as an apprentice at a lithographic press run by the sister of Mark Antokolsky. Initially hoping to study in Vienna, he was re-routed back to Russia and reached Odessa. There, sometimes destitute, he supported himself as a sign painter until he was accepted to the Academy of Fine Arts. He joined the expeditions to Kishinev in the aftermath of the 1903 pogrom, some led by H. N. Bialik (1873-1934). During

25 This portrait was later copied, possibly by Schatz himself. See: https://www.foxnews.com/world/would-the-real-jozef-israels-please-stand-up-israeli-curators-crack-a-mysterious-forgery

26 See: Berger 2017: 421-458. Many early pieces of Bezalel are yet to be found in museum collections across the United States. Schatz was particularly successful among the Reform congregations in the USA. For Cincinnati, see: https://huc.edu/research/museums/skirball-museum-cincinnati/exhibition-archive/boris-schatz-collection-huc-jir 


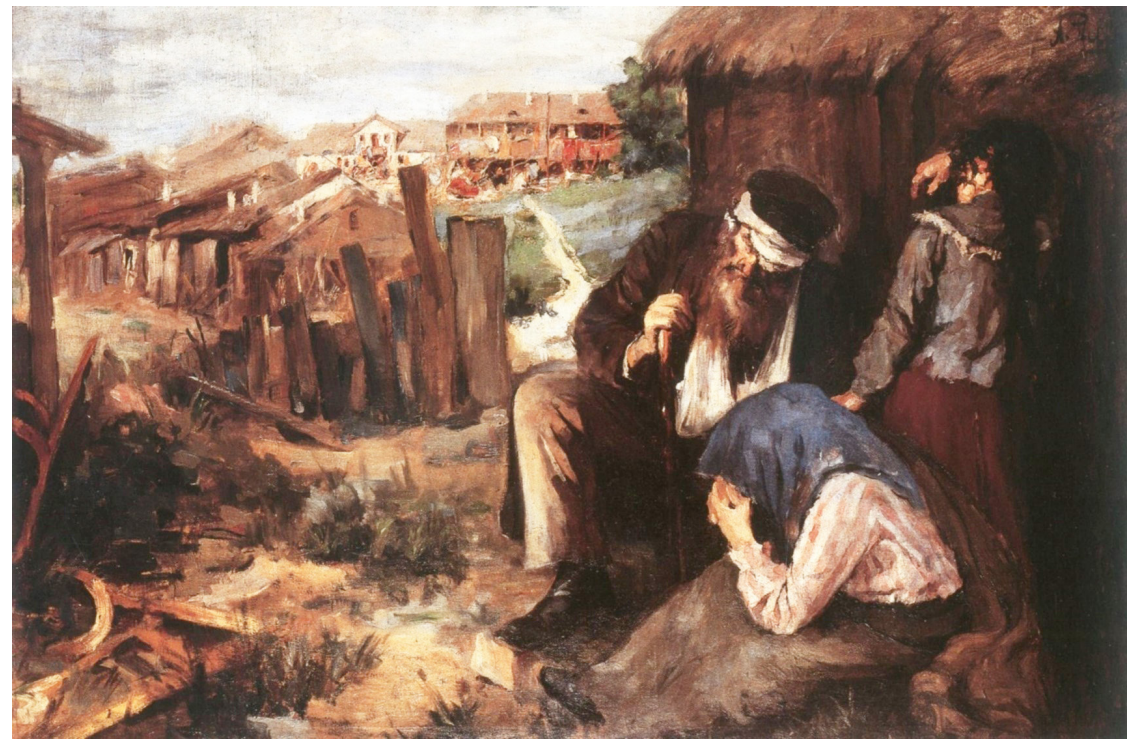

Fig. 9. Abel Pann. Day after the Pogrom (Yard in Ruins and Bereaved Family), [Kishinev Pogrom]. 1903.

Oil on canvas, $119 \times 176 \mathrm{~cm}$. Private collection

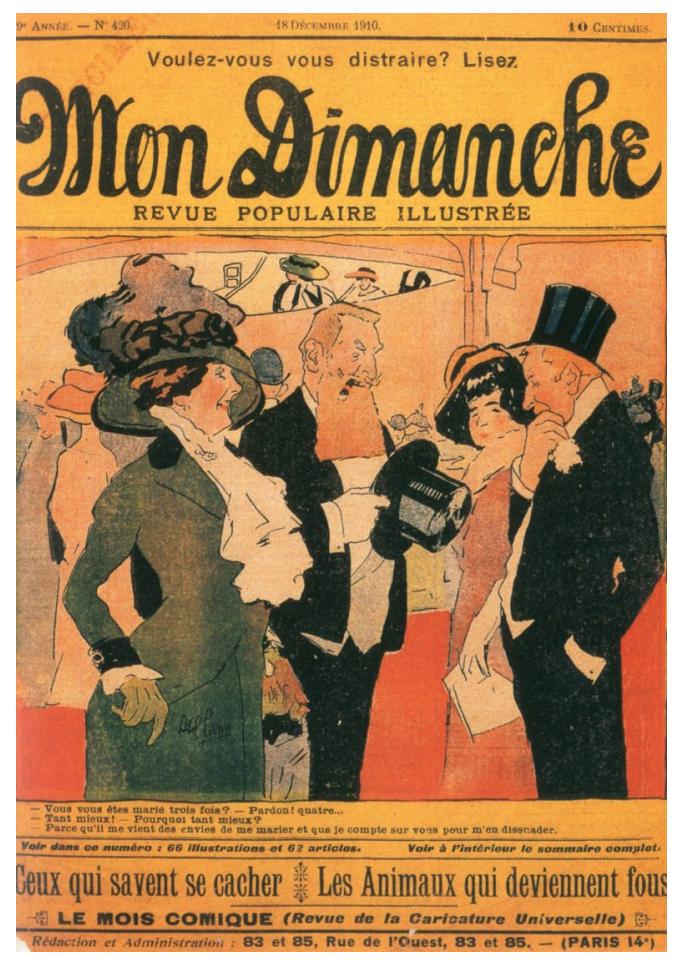

Fig. 10. Abel Pann. Cover illustration for the Mon Dimanche. Paris, 18 December 1910. Courtesy Collection Itiel Pann, Jerusalem this period, Pann painted scenes of refugees (Fig. 9) and Jewish beggars in oils in a realistic style related to the Russian artists' association Peredvizhniki (The Wanderers). His work sparked the interest of the Russian art critic and promoter of national art Vladimir Stasov and the art patron Baron David Günzburg, who financed his journey to Paris.

From 1904 to 1913, Pann resided at La Ruche, an artist enclave in the Montparnasse district, and studied at the Académie Julian under William Adolphe Bourguereau (1825-1905) and Edouard Toudouze (1848-1907). As can be seen in a series of autobiographical ink drawings at the age of 17 , he had a natural inclination to caricature and from 1908 to 1912 he drew for the magazines Le Rire (Laughter) and Mon Dimanche (My Sunday) (Fig. 10). These illustrations in solid patches of colour 
with clearly defined contours reflect the style of Jean-Louis Forain (1852-1931), Alexandre Théophile (1859-1923), and Henri de Toulouse-Lautrec (1864-1901). He also produced small oil paintings and gouaches of local genre scenes. Pann participated in the Salon des Indépendants and sold a work to the Musée du Luxembourg. In 1911, he exhibited alongside Matisse and Renoir, and the influence of the latter left an imprint on the colouring of his pastel work.

In 1912, at the home of the sculptor Naum Aronson (18721943), his fellow compatriot from Kreslawka, Pann met Schatz, who invited him to join the staff of the Bezalel School of Art in Jerusalem. Following a trip to southern Europe, Spain, and Egypt, in 1913

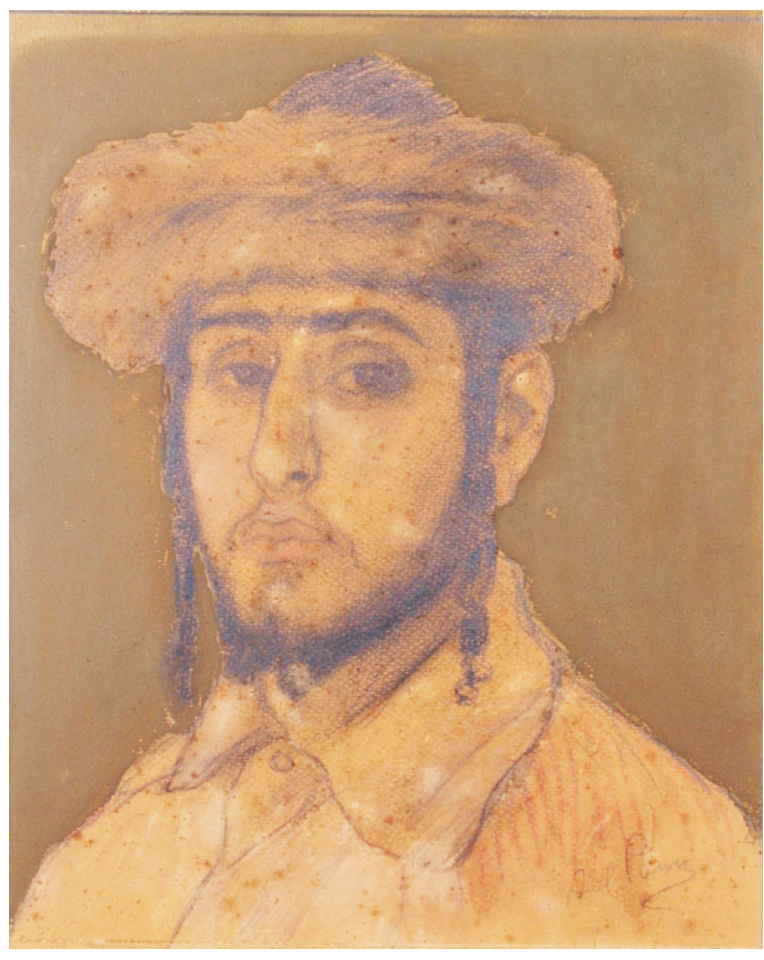

Fig. 11. Abel Pann. Le jeune savant. 1913. From the series "Jerusalem Types". Gouache and pencil on cardboard, $43 \times 35 \mathrm{~cm}$. Collection of the Tel Aviv Museum of Art Pann arrived at the Bezalel where he promoted plein air painting and introduced the students to the French masters. In 1914, he returned to Paris for personal reasons, and it was only in 1920 that he was able to return to the Bezalel School, where he taught until 1924.

In the interim, Pann worked on a series of pastel illustrations entitled "Jug of Tears", (1916), depicting ravages of the First World War inflicted on the Galician Jews in the manner of Francisco Goya's (1746-1828) Los Desastres de la Guerra (The Disasters of War, 1810-1820). The series, also called "By Order of the Czar", criticized Russian soldiers and antagonized the French government who forbade its public exhibition, whereupon Pann left for a tour of the series in the USA from 1918 to 1920.

A rare work in the collection comes from Pann's first visit to Palestine in 1913, when he embarked on a series entitled "Jerusalem Types", which focused on the Ashkenazi community of the Old Yishuv. The gouache portrait, with a heavy pencil under-drawing, was the basis for a colour lithograph and print entitled "Le jeune savant" (The Young Scholar, c. 1913) (Fig. 11). The young Jew, looking left with a quizzical glance, is wearing a buttoned-up shirt and a striped caftan over it. He has long 


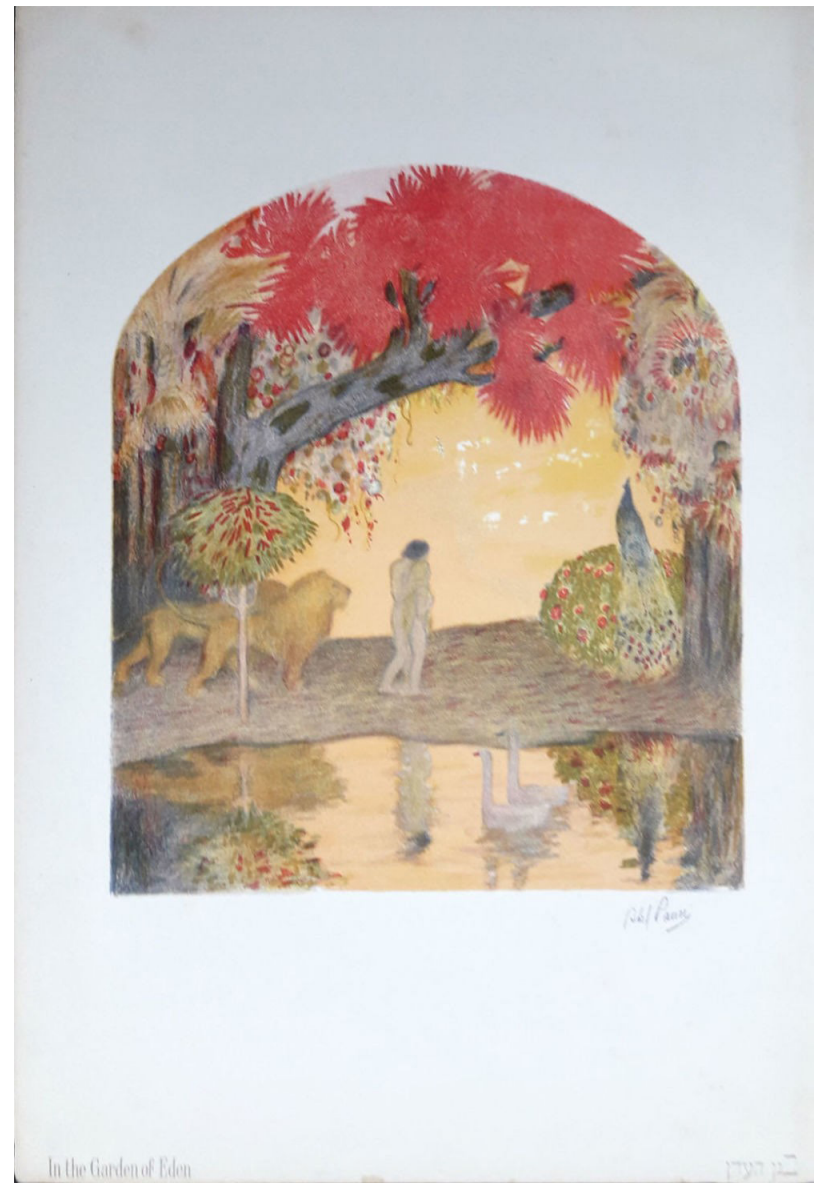

Fig. 12. Abel Pann. In the Garden of Eden. Around 1924. Colour lithograph, $44.1 \times 29.8 \mathrm{~cm}$; signed lower right in the stone: "Abel Pann". Collection of the Tel Aviv Museum of Art ear-locks and is wearing a streimel, a fox-tail hat typical of the Hasidic Jews.

In 1913, Pann embarked on his major life work, which was to illustrate the Hebrew Bible, although he completed only the first book of Genesis and part of Exodus. Altogether, Pann produced over 500 pastels and lithographs on Biblical themes. In order to enliven the work, he based himself on the indigenous ethnic groups (Oriental Jews and Bedouin Arabs), seeking to instil in them more emotion than in the $\mathrm{Bi}$ ble illustrations by Jacques Joseph Tissot (1836-1902) published in Paris in 1904. The early works of the $1920 \mathrm{~s}$ consist of delicate soft-ground monochromatic lithographs. ${ }^{27}$ These were followed by pastel and lithograph versions in passionate colour. In the Bible illustrations of the 1940s and 1950s, Pann sometimes reverted to expansive emotion in an extreme manner that bordered on the grotesque.

The Tel Aviv Museum of Art has one of many of the published series of 25 lithographs on the Bible, printed on the lithographic press that Pann brought to Bezalel from Vienna in 1921 when he established the Graphica workshop at Bezalel. In the Museum copy of the book, there is an extra plate of the Garden of Eden (Fig. 12). In the idyllic scene amid Fauvist colour harmony of bright red foliage against an orange-yellow sky, nude Adam and Eve are walking in Paradise alongside a pond; their images, as well as those of a peacock on the right and a lion and lioness on the left, are reflected in the water, while two swans are gliding by.

Pann died in 1963, in Jerusalem. 


\section{Conclusions}

The Bezalel School of Art (1906-1929) was a Zionist enterprise with competing goals and narratives. The Berlin Zionist Organization, one of the main funders of the school, sought to establish a carpet industry. On the other hand, the founder of the school, Prof. Boris Schatz, sought to instil a national artistic style, a unique "Hebrew" style based on archaeological motifs, biblical stories and figures, which were largely based on the indigenous peoples, mainly the Yemenite Jews and Arab population, on the use of the Hebrew script, and traditional silversmith and coppersmith techniques. However, in reality it was not a grassroots institution: the designers of Bezalel artefacts, such as Ze'ev Raban, were trained in Europe and imposed their designs on the local artisans. In his marketing endeavours in the United States, Schatz promoted a "Jewish Room" that would showcase Bezalel objects. However, although many of the teachers in the school, including Schatz, came from religious backgrounds, they were secular in their outlook. And even those ceremonial objects were supposed to be meaningful in a national rather than religious manner. For this reason, the Reform movement was one of his better customers. The "Hebrew" national style was believed to represent the Halutz or a pioneer to Mandatory Palestine as an alternative to the Galut or a Diaspora Jew whose artistic representatives were shtetl scenes, religious observances, and depictions of pogroms and other disasters.

Abel Pann was an artist who bridged these styles, and his oeuvre ranges from early depictions of pogroms to vibrant biblical illustrations. These endeavours of Schatz and his staff did result in a distinct style, especially in regard to ceremonial and home objects; it was a style that continued long after the Bezalel School of Art closed in 1929. However, Schatz was not able to distance himself from the romanticism and the academic nature of his early art studies. As a result, the students moved on to more modernist schools of art, reaching to the abstract or lyrical abstract in their work, leading to the New Horizons group. ${ }^{28}$

Received 4 October 2017 Accepted 27 April 2020

\section{References}

1. Ashbee, C.R. A Palestine Notebook, 1918-23. London: William Heinemann, 1923, 247-8, quoted in: Menachem Levin, "Charles Robert Ashbee - Restoration of the Citadel and the Establishment of the Tower of David Museum," in The Tower of David Days: First Cultural Strife in Israeli Art. Jerusalem: Tower of David Museum of the History of Jerusalem, 1991, 74 [exhibition catalogue].

2. Balas, G. New Horizons: The Birth of Abstraction in Israeli Art. Tel Aviv: Modan Publishers, 2014.

3. Berger, N. The Jewish Museum, History and Memory, Identity and Art from Vienna to the Bezalel National Museum, Jerusalem. Leiden-Boston: Brill, 2017. 
4. Donner, B. Between Collection and Museum, From the Peremen Collection through the Tel Aviv Museum. Catalog. Tel Aviv: Tel Aviv Museum of Art, 2002.

5. Günzburg, B. D.; Stasov, V. L’Ornement Hébreu. Berlin: Cavalry, 1905.

6. Herzl, T. The Jewish State (1896). New York: Dover Publications, Inc., 1988.

7. Pann, A. The Bible in Pictures, Painted in the Holy Land. Jerusalem: Palestine Art Publication, 1926).

8. Schatz, B. Bezalel: History, Essence and Future. Jerusalem: Snunit, 1910.

9. Schatz, B. On Art, Artists and Their Critics. Jerusalem: Bnei Bezalel, 1924: 15-17. In Hebrew.

10. Schatz, B. Boris Schatz - His Life \& Work, a Monograph, Jerusalem: B’nai Bezalel, 1925.

11. Sefer Raziel ha'Malakh (in Hebrew). Amsterdam: Avraham Mendes Qavitinyo, 1701.

12. Širkaitè, J. Académie de Vilna. Vilniaus piešimo mokykla 1866-1915. Vilnius Drawing School 1866-1915. Catalog. Vilnius: Lietuvos kultūros tyrimų institutas, 2017.

13. Vasilieva, O.; Zaikovsky, B.; Kantsedikas, A. Hebrew Manuscript Ornaments. From the series Masterpieces of Jewish Art. Moscow-Tel Aviv: Image Publishing House, 2003.

14. Voiskoun, L. Odessa Parisians, Modernist Art from the Peremen Collection. Ramat Gan: Maria and Mikhail Zetlin Museum of Russian Art, 2006 [exhibition catalogue]

15. Ramat Gan: Maria and Mikhail Zetlin Museum of Russian Art, 2006 [exhibition catalogue].

16. Zalmona, Y. Tower of David Days: First Cultural Strife in Israel Art. Jerusalem: The Israel Museum, 1991 [exhibition catalogue].

\section{Batsheva Goldman-Ida}

\section{Borisas Schatzas, Abelis Pannas ir Becalelio dailès ir amatu mokykla Jeruzalèje}

\section{Santrauka}

Šiame trumpame straipsnyje apie Becalelio dailès ir amatų mokyklą (1906-1929) pateikiami prieštaringi pasakojimai apie Berlyno sionistų komitetą, parèmusị šios mokyklos įkūrimą, ir jos ịkūrèją profesorių Borisą Schatzą. Vieni Becalelio mokyklą matė kaip pajamų šaltinị, galintị ją išlaikyti, kiti svajojo sukurti naują, nacionalinị hebrajų tautos meno stilių. Dèl šių nesuderinamų lūkesčių kilę nesutarimai netgi privertė uždaryti mokyklą. Borisas Schatzas daugiausia kūrè skulptūras ir tik vèliau, susilpnėjus sveikatai, paskutiniaisiais gyvenimo metais rimčiau ėmėsi tapybos. Dailininkas Ze'evas Rabanas (Wolf Rawicki), atèjęs ị mokyklos kolektyvą 1912 m., sukūrè daugumą buitinès ir religinès paskirties taikomosios dailès kūrinių, iliustravo biblinius pasakojimus. $1913 \mathrm{~m}$. prie dèstytojų kolektyvo prisijungè Abelis Pannas (Abba Pfeffermannas). Abu šie Europoje išsilavinimą igiję dailininkai buvo pajègūs išmokyti studentus šiuolaikinių tapybos ir skulptūros technologijų, îskaitant ir tapymą plenere, o Pannas $1921 \mathrm{~m}$. i J Jeruzalę atgabeno pirmąji litografijos presą. RAKTAŽODŽIAI: Becalelio dailès ir amatų mokykla, Borisas Schatzas, Ze'evas Rabanas, Abelis Pannas 